\title{
PENINGKATAN KEMAMPUAN PERHITUNGAN MATEMATIKA ANUITAS MASYARAKAT DESA AI BUKAQ LOMBOK TENGAH
}

\author{
Vera Mandailina', \\ 1Pendidikan Matematika, Universitas Muhammadiyah Mataram, vrmandailina@ummat.ac.id
}

\begin{abstract}
ABSTRAK
Abstrak: Kegiatan ini dilakukan untuk meningkatkan kemampuan perhitungan anuitas masyarakat di Lombok Tengah. Kegiatan berlangsung selama 1 bulan termasuk perencanaan sampai evaluasi. Perserta kegiatan ini adalah para ibu-ibu rumah tangga, bapak-bapak dan remaja masjid Desa Ai Bukak. Kegiatan dilakukan dalam bentuk pelatihan dengan nara sumber dari Universitas Muhammadiyah Mataram. Tahap awal para peserta diberikan materi tentang anuitas, kemudian tahap berikutnya diberikan contoh kasus untuk diselesaikan. Adapun perhitungan menggunakan alat bantu (kalkulator) Casio. Hasil kegiatan ini sangat membantu masyarakat dalam menentukan pilihan dalam hal menabung, deposito, atau meminjam uang ke sebuah lembaga seperti Bank dan Koperasi dalam membangun usahanya.
\end{abstract}

Kata Kunci: Anuitas, Masyarakat.

Abstract: This activity is done to improve the calculation ability of community annuity in Central Lombok. Activity lasts for 1 month including planning until evaluation. Participants of this activity are the housewives, fathers and youth of Ai Bukak village mosque. The activities were conducted in the form of training with resource persons from Muhammadiyah University of Mataram. The initial stage of the participants is given material about the annuity, then the next stage is given case examples to be completed. The calculation using the tool (calculator) Casio. The results of this activity greatly assist the community in determining the choice in terms of saving, depositing, or borrowing money to an institution such as Bank and Cooperative in building its business.

Keywords: Annuities, Society

Riwayat Artikel: Diterima: 10-11-2017, Disetujui: 13-12-2017 


\section{A. LATAR BELAKANG}

Aplikasi matematika meliputi bidang eksakta, sosial humaniora, ekonomi, bahkan politik. Hal ini karena memang setiap aktivitas manusia baik secara individual maupun sosial tidak luput dari perhitungan. Salah satu konsep matematika yang baru-baru ada diterapkan dalam kurikulum pendidikan sekolah dasar dan menengah adalah Kurikulum 2013 atau K13. Dalam kurikulum ini terdapat materi baru yakni Anuitas.

Konsep anuitas banyak ditemukan dalam matematika bisnis atau ekonomi, misalnya dalam perhitungan, simulasi dan prediksi perkembangan keuangan baik sebagai pinjaman maupun sebagai deposito di lembaga sejenis Bank ataupun koperasi. Secara khusus anuitas berbicara tentang modal awal tabungan atau deposito, bunga, tingkat persentase bunga, modal akhir dan jangka waktu menabung atau deposito uang.

Di Lombok Tengah tepatnya di Desa Ai Bukaq beberapa anggota masyarakat dari kalangan Ibu-ibu Rumah Tangga sering meminjam uang di sebuah koperai atau Bank konvensional untuk memenuhi kebutuhan hidup sehari-hari bahkan untuk untuk kebutuhan modal usaha. Rata-rata para peminjam modal (masyarakat) tidak mengetahui konsep perhitungan bunga uang yang menjadi cicilan atau setoran perbulan mereka. Padahal jika mereka mengetahui konsep perhitungan tersebut setidaknya mereka tidak mudah ditipu dengan peredaran bunga di kalangan masyarakat, di samping sebagai pengetahuan tambahan bagi masyarakat. Oleh sebab itulah, kami dari tim pengabdian Universitas Muhammadiyah Mataram ingin memberikan pelatihan yang bertujuan untuk meningkatkan pemahaman konsep anuitas kepada masyarakat.

\section{B. ANUITAS}

Anuitas dalam teori keuangan adalah suatu rangkaian penerimaan atau pembayaran tetap yang dilakukan secara berkala pada jangka waktu tertentu. Contohnya adalah bunga yang diterima dari obligasi atau dividen tunai dari suatu saham preferen. Ada dua jenis anuitas:

1. Anuitas biasa (ordinary) adalah anuitas yang pembayaran atau penerimaannya terjadi pada akhir periode, serta

2. Anuitas jatuh tempo (due) adalah anuitas yang pembayaran atau penerimaannya dilakukan di awal periode.

Pinjaman sebesar $\mathrm{M}$ dibayar dengan $\mathrm{n}$ kali anuitas dgn suku bunga i. Besarnya anuitas yang dibayarkan digambarkan dalam rumus berikut.

$$
\mathrm{A}=M \cdot \frac{1}{a_{n}} \text { atau } A=\frac{i M}{1-(1+i)^{-n}}
$$

Sedangkan besar pinjaman sebagai berikut:

$$
\begin{aligned}
\text { 1. } \mathrm{a}_{\mathrm{n}}=\mathrm{a}_{\mathrm{k}} & (1+\mathrm{i})^{\mathrm{n}-\mathrm{k}} \\
\text { 2. } \mathrm{a}_{\mathrm{n}} & =\mathrm{A}-\mathrm{b}_{\mathrm{n}} \\
\mathrm{A} & =\text { Anuitas } \\
\mathrm{a}_{\mathrm{n}} & =\text { angsuran periode ke-n } \\
\mathrm{b}_{\mathrm{n}} & =\text { bunga periode ke-n } \\
\mathrm{a}_{\mathrm{k}} & =\text { angsuran periode ke-k }
\end{aligned}
$$




\section{METODE PELAKSANAAN}

Kegiatan ini dilakukan menggunakan teknik observasi dan interview dalam pengumpulan data. Sedangkan pelaksanaan dilakukan dengan cara memberikan pelatihan kepada masyarakat yakni ibu-ibu dan remaja-remaji tentang konsep perhitungan anuitas.

Adapun tahapan dalam kegiatan pengabdian ini terdiri dari 4 tahap yakni:

1. Survey lapangan. Pada tahap ini tim melakukan survey terhadap kemampuan atau pemahaman masyarakat terkait konsep anuitas serta melakukan survey terkait lokasi pelatihan.

2. Persiapan. Pada tahap ini tim melakukan persiapan terkait lokasi, surat menyurat, penyebaran informasi, dokumentasi, dan sarana prasarana lainnya.

3. Pelaksanaan. Pada tahap ini tim pengabdian melakukan pelatihan kepada masyarakat di SDN Kemasan Desa Ai Bukaq.

4. Pelaporan. Pada tahap ini tim membuat laporan dan publikasi.

\section{HASIL DAN PEMBAHASAN}

\section{Waktu Efektif Pelaksanaan}

Kegiatan ini telah dilaksanakan mulai tanggal 09 Oktober - 09 Nopember 2017. Adapun rincian kegiatan sesuai Tabel 1 di bawah ini.

TABEL 1

WAKTU EFEKTIF PELAKSANAAN PENGABDIAN

\begin{tabular}{|c|l|l|}
\hline No & \multicolumn{1}{|c|}{ Kegiatan } & \multicolumn{1}{c|}{ Pelaksanaan } \\
\hline 1 & Survey lapangan & $9-18$ Oktober 2017 \\
\hline 2 & Persiapan & $19-27$ Oktober 2017 \\
\hline 3 & Pelaksanaan & $28-29$ Oktober 2017 \\
\hline 4 & Pelaporan & 31 Oktober - 09 Nopember 2017 \\
\hline
\end{tabular}

\section{Kontribusi Mitra Dalam Kegiatan}

Selama pelaksanaan kegiatan, mitra memberikan konstribusi sebagai berikut:

a. Memberikan saran atau sumbangsih dalam menentukan teknik dan lokasi pelaksanaan pelatihan.

b. Membantu dalam sistem administrasi

c. Menyiapkan sarana dan prasarana yang dibutuhkan selama pelaksanaan kegiatan pengabdian.

\section{Potret Permasalahan Lain yang Terekam}

Selama pelaksanaan kegiatan pengabdian terdapat beberapa permasalahan lain yakni:

a. Kemampuan berhitung mahasiswa masih kurang.

b. Kemampuan masyarakat dalam menggunakan alat bantu hitung (kalkulator) masih kurang.

c. Antusias masyarakat untuk mengetahui konsep anuitas masih minim.

\section{Hasil Capaian dan Luaran}

a. Meningkatnya kemampuan dan pemahaman (soft skill dan hard skill) masyarakat Desa Ai Bukaq terkait anuitas. 